Published in final edited form as:

Phytochemistry. 2013 July ; 91: 229-235. doi:10.1016/j.phytochem.2012.02.021.

\title{
Labdane Diterpenoids from Leonotis leonurus
}

\author{
Hankui Wu ${ }^{a, d}$, Jun $\mathrm{Li}^{\mathrm{a}}$, Frank R. Fronczek ${ }^{\mathrm{e}}$, Daneel Ferreira ${ }^{\mathrm{a}, \mathrm{b}}$, Charles L. Burandt $\mathrm{Jr}^{\mathrm{c}}$, \\ Vincent Setola ${ }^{f}$, Bryan L. Roth ${ }^{\dagger}$, and Jordan K. Zjawiony ${ }^{a, b,{ }^{*}}$ \\ aDepartment of Pharmacognosy, School of Pharmacy, University of Mississippi, University, MS \\ 38677-1848, USA \\ ${ }^{b}$ Research Institute of Pharmaceutical Sciences, School of Pharmacy, University of Mississippi, \\ University, MS 38677-1848, USA \\ 'National Center for Natural Products Research, University of Mississippi, University, MS \\ 38677-1848, USA \\ ${ }^{\mathrm{d} C o l l e g e}$ of Chemistry and Chemical Engineering, Anyang Normal University, Anyang 455002, \\ China, \\ eDepartment of Chemistry, Louisiana State University, Baton Rouge, LA 70803-1804,USA \\ fDepartment of Pharmacology, School of Medicine and NIMH Psychoactive drug Screening \\ Program, University of North Carolina, Chapel Hill, NC 27599, USA
}

\section{Abstract}

Three known (leoleorins A-C) and eight new (leoleorins D-J and 16-epi-leoleorin F) labdane diterpenoids, were isolated from leaves of Leonotis leonurus. The absolute configurations of leoleorins A and D were established by X-ray crystallographic analyses. In competitive binding assay all isolated compounds showed inhibition in excess of 50\% at various CNS receptors. Leoleorin $\mathrm{C}$ showed moderate binding affinity $\left(K_{i}=2.9 \mu M\right)$ for the Sigma 1 receptor.

\section{Keywords}

Leonotis leonurus; Lamiaceae; Psychoactive plant; Labdane diterpenoids; Leoleorins A-J; X-ray diffraction; G-protein-coupled receptors

\section{Introduction}

Leonotis leonurus (L.) R. Br. (Lamiaceae), also known as Lion's Tail or Wild Dagga, is commonly used in Southern Africa to treat fevers, headaches, dysentery, flu, chest infections, epilepsy, constipation, delayed menstruation, intestinal worms, spider bites, scorpion stings, hypertension, and snake bites (Iwarsson, 1985; Stafford et al., 2008). It is also known for its mild psychoactive properties. The dried leaves and flowers have a mild

\footnotetext{
(C) 2012 Elsevier Ltd. All rights reserved.

*To whom correspondence should be addressed. Tel: +1 662915 7290. Fax: +1 662915 6975. jordan@ olemiss.edu.

Publisher's Disclaimer: This is a PDF file of an unedited manuscript that has been accepted for publication. As a service to our customers we are providing this early version of the manuscript. The manuscript will undergo copyediting, typesetting, and review of the resulting proof before it is published in its final citable form. Please note that during the production process errors may be discovered which could affect the content, and all legal disclaimers that apply to the journal pertain.

Appendix A. Supplementary data

Supplementary data associated with this article (The ${ }^{1} \mathrm{H},{ }^{13} \mathrm{C}$ NMR spectra of compounds $\mathbf{1 - 8}$, and crystallographic data for $\mathbf{1}$ and 9 and primary binding results in biological test) can be found, in the online version,
} 
calming effect when smoked, which is similar to the effect of the THC cannabinoid found in Cannabis. It has also been reported to cause mild euphoria, visual changes, dizziness, nausea, sweating, sedation, and light headedness. The picked and dried leaves are also commonly brewed as a minty tea. Research showed that it could be used to benefit people with anxiety and depression due to its calming effects. L.leonurus has been proposed to modulate dopaminergic system (Stafford et al., 2008). Water and lipid extracts of the leaves showed anticonvulsant (Bienvenu et al., 2002), antinociceptive (Ojewole, 2005), antiinflammatory (Ojewole, 2005; Stafford et al., 2005), antidiabetic (Ojewole, 2005; Oyedemi et al., 2011), antibacterial (Stafford et al., 2005; Scott et al., 2004; Jimoh et al., 2010), antioxidant (Jimoh et al., 2010; Frum and Viljoen, 2006), and anthelmintic (Maphosa et al., 2010) activities.

Previous phytochemical analysis of extracts of $L$. leonurus indicated the presence of tannins, alkaloids, as well as steroidal and triterpenoid saponins (Bienvenu et al., 2002). Organic extracts of the flowering parts of the plant provided flavonoids and acyclic diterpene esters (El-Ansari et al., 2009; Agnihotri et al., 2009), while the leaves contained mostly labdane diterpenoids (Cragg and Little, 1962; Rivett, 1964; Kaplan and Rivett, 1968; Laonigro et al., 1979; Kruger and Rivett, 1988; McKenzie at al., 2006; Obikeze et al., 2008; Naidoo et al., 2011). Herein, the isolation and structure elucidation of eight new (1-8) and three known (9-11) labdane diterpenoids (Fig. 1) from this species are reported. In collaboration with the National Institute of Mental Health Psychoactive Drug Screening Program (NIMH-PDSP), in vitro receptor screening of all pure isolates resulted in identification of the active constituents of $L$. leonurus.

\section{Results and discussion}

\subsection{Structural elucidation of compounds}

A Leoleorin D (1), was obtained as colorless crystals, $[\alpha]_{\mathrm{D}}^{23}-7.5$, and was established to have a molecular formula of $\mathrm{C}_{20} \mathrm{H}_{36} \mathrm{O}_{4}$ by HR-ESIMS $\left(\mathrm{m} / \mathrm{z} 363.2499[\mathrm{M}+\mathrm{Na}]^{+}\right)$. In the ${ }^{1} \mathrm{H}$ NMR spectrum, singlets representing three tertiary methyl groups at $\delta_{\mathrm{H}} 1.01,1.24$, and 1.27, and a doublet of one secondary methyl group at $\delta_{\mathrm{H}} 0.93(\mathrm{~J}=6.8 \mathrm{~Hz})$ were evident. The ${ }^{13} \mathrm{C}$ NMR and DEPT spectra exhibited 20 carbon resonances $\left(4 \times \mathrm{C}, 3 \times \mathrm{CH}, 9 \times \mathrm{CH}_{2}\right.$, and $4 \times$ $\mathrm{CH}_{3}$ ). There were signals of two oxygenated quaternary carbons at $\delta_{\mathrm{C}} 94.1$ and 85.3, characteristic features of the oxygenated carbon of a spirotetrahydrofuran moiety, two oxymethylene groups [ $\delta_{\mathrm{C}} 66.8 ; \delta_{\mathrm{H}} 3.50(\mathrm{H}-16 \mathrm{a}, \mathrm{d}, J=10.8 \mathrm{~Hz})$ and $\delta_{\mathrm{H}} 3.62(\mathrm{H}-16 \mathrm{~b}, \mathrm{~d}, J=$ $\left.10.8 \mathrm{~Hz}) ; \delta_{\mathrm{C}} 59.6 ; \delta_{\mathrm{H}} 3.85\left(\mathrm{H}_{2}-15, \mathrm{~m}\right)\right]$, and one oxymethine group [ $\left.\delta_{\mathrm{C}} 68.0 ; \delta_{\mathrm{H}} 4.36(\mathrm{br} \mathrm{s})\right]$. The molecular formula requiring three degrees of unsaturation, in conjunction with the absence of UV absorption and $\mathrm{sp}^{2}$ or sp carbon resonances, suggested a highly oxygenated tricyclic labdane diterpenoid skeleton for $\mathbf{1}$, similar to the structure of lagochilin (Chizhov et al., 1979). In the HMBC spectrum, correlations of H-6 with C-4, C-5, C-7, C-8, C-10, Me-17 with C-7, C-8, C-9, Me-20 with C-1, C-5, C-9, C-10, as well as Me-18 and Me-19 with C-3, C-4, and C-5, were used to assign the hydroxy group to C-6. The known $a$ orientation of $\mathrm{H}-5$ in labdane diterpenoids (Wu et al., 2011), and the coupling profile (br s) of H-5 and H-6 indicated the cis-arrangement of these two protons in an $a$-axial, $a$ equatorial orientation, with the 6-OH $\beta$-axially oriented. Thus, the structure of 1 was proposed as 9,13-epoxylabdane-6 $\beta, 15,16$-triol. X-ray crystallographic data of $\mathbf{1}$ (Fig. 2) further defined its absolute configuration and structure as $(5 S, 6 R, 8 R, 9 R, 10 S, 13 S)-9,13$ epoxylabdane-6,15,16-triol.

Leoleorin $\mathrm{E}$ (2), was isolated as a colorless oil, $[\alpha]_{\mathrm{D}}^{23}-3.3$, and its molecular formula was determined to be $\mathrm{C}_{20} \mathrm{H}_{34} \mathrm{O}_{4}$ by HR-ESIMS $\left(\mathrm{m} / \mathrm{z} 361.2351[\mathrm{M}+\mathrm{Na}]^{+}\right)$. The ${ }^{1} \mathrm{H}$ and ${ }^{13} \mathrm{C}$ NMR spectroscopic data (Tables 1 and 2) indicated the presence of a C-15 hemiacetal 
carbon $\left(\delta_{\mathrm{C}} 98.9, \mathrm{CH} ; \delta_{\mathrm{H}} 5.41, \mathrm{~d}, J=4.8 \mathrm{~Hz}\right)$ rather than a $\mathrm{C}-16$ hemiacetal, due to the presence of the $\mathrm{H}_{2}-16$ resonances at $\delta_{\mathrm{H}} 3.55(\mathrm{~d}, J=8.8 \mathrm{~Hz})$ and $4.27(\mathrm{~d}, J=8.8 \mathrm{~Hz})$. The HMBC correlations showed similar relationships as in 1, except for the presence of correlations between $\mathrm{H}_{2}-16$ and $\mathrm{C}-15$, and $\mathrm{H}_{2}-15$ and $\mathrm{C}-16$. The relative configuration of 2 was assigned on the basis of NOESY correlations (Fig. 3). Based on the assumed $5 S$ configuration for labdane diterpenoids and the NOEs between Me-17 and $\mathrm{H}_{2}-14$ and between $\mathrm{H}-16 \mathrm{a}\left(\delta_{\mathrm{H}} 4.27\right)$ and $\mathrm{H}-1 a\left(\delta_{\mathrm{H}} 1.89\right)$, which are consistent with a $13 S$ configuration of the spirocyclic D-ring. The $\beta$-orientation of $\mathrm{H}-15$ was concluded from a NOESY correlation between $\mathrm{H}-15$ and $\mathrm{H}-12 \beta\left(\delta_{\mathrm{H}} 1.92, \mathrm{~m}\right)$. The NOESY spectrum showed correlations of Me-18 $\left(\delta_{\mathrm{H}} 0.97, \mathrm{~s}\right)$ with $\mathrm{H}-5\left(\delta_{\mathrm{H}} 1.31\right)$ and $\mathrm{H}-6\left(\delta_{\mathrm{H}} 4.34\right)$, indicating the proximity of these protons. Since Me-18 and H-5 in labdanes are $a$-oriented, H-6 will be $a$ equatorial. Consequently, the 6-OH has a $\beta$-axial orientation. Based on these data, 2 was identified as 9,13:15,16-diepoxylabdane-6 $\beta, 15 a$-diol.

Leoleorin $\mathrm{F}(\mathbf{3})$ was isolated as a colorless oil, $[\alpha]_{\mathrm{D}}^{23}-21.6$, and its molecular formula was determined to be $\mathrm{C}_{20} \mathrm{H}_{34} \mathrm{O}_{4}$ by HR-ESIMS $\left(\mathrm{m} / \mathrm{z} 361.2357[\mathrm{M}+\mathrm{Na}]^{+}\right)$. The ${ }^{1} \mathrm{H}$ and ${ }^{13} \mathrm{C}$ NMR (Tables 1 and 2), and HSQC data confirmed the presence of three tertiary methyl groups $\left[\delta_{\mathrm{H}} 1.24(\mathrm{~s}), 1.20(\mathrm{~s})\right.$, and $\left.0.97(\mathrm{~s})\right]$, one methyl doublet at $\delta_{\mathrm{H}} 0.88(\mathrm{~d}, J=6.8 \mathrm{~Hz})$, two oxygenated quaternary carbons $\left(\delta_{\mathrm{C}} 94.3,90.6\right)$, one oxymethylene group $\left[\delta_{\mathrm{C}} 64.9 ; \delta_{\mathrm{H}}\right.$ $4.09(\mathrm{~m}), 3.77(\mathrm{~m})]$, and a hemiacetal group $\left[\delta_{\mathrm{C}} 98.8 ; \delta_{\mathrm{H}} 4.70(\mathrm{~s})\right]$. With four degrees of unsaturation and the absence of $\mathrm{sp}^{2}$ or sp carbon resonances and UV absorption, compound 3 should be a labdane diterpenoid with a spirotetrahydrofuran structural moiety. The NMR spectroscopic data are similar to those of 9,13:15,16-diepoxylabdane-6 $\beta, 16$-diol (Naidoo et al., 2011), which has been identified as an $a, \beta$ anomeric mixture at $\mathrm{C}-16$ with the configuration of C-13 undetermined. In the NOESY spectrum (Fig. 4), NOEs were detected between Me-18 $\left(\delta_{\mathrm{H}} 0.97\right)$ and $\mathrm{H}-5\left(\delta_{\mathrm{H}} 1.33\right)$, Me-18 and H-6 $\left(\delta_{\mathrm{H}} 4.34\right)$, Me-20 $\left(\delta_{\mathrm{H}} 1.24\right)$ and $\mathrm{H}-11\left(\delta_{\mathrm{H}} 2.14,2.09\right), \mathrm{Me}-20$ and $\mathrm{H}-8\left(\delta_{\mathrm{H}} 2.11\right)$ establishing the relative configurations at C-5, C-6, C-8, C-9, and C-10. Similarly to compound 2, the configuration at C-13 was determined as $S$ from the NOE correlations between $\mathrm{H}-1 a\left(\delta_{\mathrm{H}} 1.47\right)$ and $\mathrm{H}-16\left(\delta_{\mathrm{H}} 4.70\right)$, between $\mathrm{H}-14\left(\delta_{\mathrm{H}} 2.35\right)$ and Me-17 $\left(\delta_{\mathrm{H}} 0.88\right)$, and the latter also confirmed the $a$ orientation of Me-17. Therefore, the structure of $\mathbf{3}$ was identified as 9,13:15,16diepoxylabdane- $6 \beta, 16 \beta$-diol.

16-epi-Leoleorin F (4), was isolated as a white powder, and its molecular formula $\mathrm{C}_{20} \mathrm{H}_{34} \mathrm{O}_{4}$ was determined to be same as that of 3 by HR-ESIMS $\left(\mathrm{m} / z 361.2359[\mathrm{M}+\mathrm{Na}]^{+}\right)$. The ${ }^{1} \mathrm{H}$ and ${ }^{13} \mathrm{C}$ NMR spectroscopic data (Tables 1 and 2) were very close to those of $\mathbf{3}$. The major difference between $\mathbf{3}$ and $\mathbf{4}$ is the opposite sign of their specific rotation $\left([\alpha]_{\mathrm{D}}^{23}+30.0\right.$ for $\mathbf{4}$, and -21.6 for 3 ), and the opposite configuration of C-16 in 4 as indicated by NOESY correlations (Fig. 5). Thus 4 was identified as a C-16 epimer of 3, 9,13:15,16diepoxylabdane-6 $\beta, 16 a$-diol.

Leoleorin $\mathrm{G}(\mathbf{5})$ was obtained as a colorless oil, $[\alpha]_{\mathrm{D}}^{23}-20.5$, and its molecular formula was determined as $\mathrm{C}_{20} \mathrm{H}_{28} \mathrm{O}_{4}$ by HR-ESIMS $\left(m / z 355.1889[\mathrm{M}+\mathrm{Na}]^{+}\right)$. Its UV maximum absorbance was at $233 \mathrm{~nm}$. The ${ }^{13} \mathrm{C}$ NMR and DEPT spectra (Table 2) showed 20 carbon resonances indicating four methyl, seven methylene (one oxymethylene at $\delta_{\mathrm{C}} 77.8$ ), two methine (including one olefinic carbon), and seven quaternary carbons. Analysis of the NMR spectroscopic data (Tables 1 and 2) established the characteristic features of an $a, \beta$ unsaturated carbonyl moiety $\left[\delta_{\mathrm{C}} 172.6(\mathrm{C}-5), 123.0(\mathrm{C}-6), 199.2(\mathrm{C}-7) ; \delta_{\mathrm{H}} 5.93(\mathrm{~s}, \mathrm{H}-6)\right]$ analogous to that present in compound $\mathrm{Y}$, which was previously isolated from the same species (Kaplan and Rivett, 1968). Additionally, the HMBC spectrum showed correlations of $\mathrm{H}_{2}-16\left[\delta_{\mathrm{H}} 4.14(\mathrm{~d}, J=8.8), 3.99(\mathrm{~d}, J=8.8)\right]$ and $\mathrm{H}_{2}-14\left[\delta_{\mathrm{H}} 2.80(\mathrm{~d}, J=17.2), 2.43(\mathrm{~d}, J\right.$ 
$=17.2)]$ with the carbonyl carbon at $\delta_{\mathrm{C}} 174.2$, indicating the presence of a five-membered lactone ring. Thus structure 5 was determined to be 9,13-epoxylabd-5-en-7-on-15,16-olide.

Leoleorin $\mathrm{H}(\mathbf{6})$, was isolated as a white powder $\left([\alpha]_{\mathrm{D}}^{23}-29.5\right)$ that gave an $[\mathrm{M}+\mathrm{H}]^{+}$ion at $\mathrm{m} / \mathrm{z} 379.2468$ in HR-ESIMS, consistent with a molecular formula of $\mathrm{C}_{22} \mathrm{H}_{34} \mathrm{O}_{5}$, requiring six degrees of unsaturation. The similarity of the UV spectra of $\mathbf{6}$ and $\mathbf{5}$ suggested the presence of an $a, \beta$-unsaturated carbonyl moiety in $\mathbf{6}$, which was also consistent with the NMR spectroscopic data (Tables 1 and 2) of the conjugated carbonyl unit $\left[\delta_{C} 172.3(\mathrm{C}-5)\right.$, $\left.122.9(\mathrm{C}-6), 199.9(\mathrm{C}-7) ; \delta_{\mathrm{H}} 5.90(\mathrm{H}-6, \mathrm{~s})\right]$. Twenty two resonances $(7 \times \mathrm{C} ; 2 \times \mathrm{CH} ; 8 \times$ $\mathrm{CH}_{2} ; 5 \times \mathrm{CH}_{3}$ ) were observed in the ${ }^{13} \mathrm{C}$ NMR and DEPT spectra (Table 2). The signals of an acetoxy group $\left[\delta_{C} 171.1\left(\mathrm{CH}_{3} \underline{\mathrm{C}}=\mathrm{O}\right), 20.9\left(\mathrm{CH}_{3} \mathrm{C}=\mathrm{O}\right) ; \delta_{\mathrm{H}} 1.90(3 \mathrm{H}, \mathrm{s})\right]$ were observed. The HMBC correlation between the acetate carbonyl carbon $\left(\delta_{\mathrm{C}} 171.1\right)$ and oxymethylene protons $\left[\delta_{\mathrm{H}} 3.93(2 \mathrm{H}, \mathrm{m}), \mathrm{H}_{2}-15\right]$, and the absence of HMBC correlation between the oxymethylene group at $\delta_{\mathrm{H}} 3.29(1 \mathrm{H}, \mathrm{d}, J=11.2), 3.38(1 \mathrm{H}, \mathrm{d}, J=11.2)$ and the acetoxy carbonyl carbon $\left(\delta_{\mathrm{C}} 171.1\right)$, showed a seco-type arrangement similar to compound $\mathbf{1}$, in which the hydroxy group at C-15 was acetylated. Thus, $\mathbf{6}$ was identified as 15 -acetoxy-9,13epoxy-16-hydroxylabd-5-en-7-one.

Leoleorin I (7), was obtained as a colorless oil, $[\alpha]_{\mathrm{D}}^{23}-36.5$, and its molecular formula was determined as $\mathrm{C}_{20} \mathrm{H}_{32} \mathrm{O}_{4}$ by HR-ESIMS $\left(\mathrm{m} / \mathrm{z} 359.2208[\mathrm{M}+\mathrm{Na}]^{+}\right)$. The ${ }^{1} \mathrm{H}$ and ${ }^{13} \mathrm{C}$ NMR spectroscopic data (Tables 1 and 2), DEPT, HMBC, HMQC and specific rotation of 7 and 6 were similar, except for the absence of resonances for the acetyl group in $\mathbf{7}$. Thus, 7 was identified as 9,13-epoxy-15,16-dihydroxylabd-5-en-7-one.

Leoleorin J (8), was obtained as a colorless oil, $[\alpha]_{\mathrm{D}}^{23}-69.6$, and its molecular formula was determined as $\mathrm{C}_{20} \mathrm{H}_{34} \mathrm{O}_{4}$ by HR-ESIMS $\left(\mathrm{m} / \mathrm{z} 361.2359[\mathrm{M}+\mathrm{Na}]^{+}\right)$. The ${ }^{1} \mathrm{H}$ and ${ }^{13} \mathrm{C}$ NMR (Tables 1 and 2), and UV spectra showed that the conjugated carbonyl moiety in 7 was replaced by an allylic alcohol functionality $\left[\delta_{\mathrm{H}} 5.57(\mathrm{~d}, J=1.6 \mathrm{~Hz}, \mathrm{H}-6), 3.95(\mathrm{dd}, J=9.2\right.$, $\left.1.6 \mathrm{~Hz}, \mathrm{H}-7) ; \delta_{\mathrm{C}} 150.2(\mathrm{C}-5), 122.5(\mathrm{C}-6), 72.1(\mathrm{C}-7)\right]$ in the structure of 8 . Judging from the molecular formula and putative bio synthetic origin, 8 may be produced by enzymatic reduction of $\mathbf{7}$ to the corresponding allylic alcohol derivative, or obtained from $\mathbf{1}$ by dehydration followed by an allylic oxidation. The $\beta$-orientation of the 7-OH group was deduced from the NOESY correlation between $\mathrm{H}-7\left(\delta_{\mathrm{H}} 3.95,1 \mathrm{H}, \mathrm{dd}, J=9.2,1.6\right)$ and Me-17 $\left(\delta_{\mathrm{H}} 1.12,3 \mathrm{H}, \mathrm{d}, J=6.8\right)$. Thus, 8 was identified as 9,13-epoxylabd-5-ene-7 $\beta, 15,16$-triol.

The remaining three compounds 9-11 were earlier reported as compound Y (Kaplan and Rivett, 1968), 9,13-epoxy-6-hydroxylabdan-15,16-olide (Naidoo et al., 2011), and semisynthetic derivative anhydro-Y (Cragg and Little, 1962; Kaplan and Rivett, 1968). Because of their structural similarity to compounds 1-8, renaming of their names to leoleorins A-C is proposed. Leoleorin A (9) was obtained as white crystals, $[\alpha]_{\mathrm{D}}^{23}-22.5$, and its ESIMS spectrum gave an ion peak at $m / z 317.2\left([\mathrm{M}+\mathrm{H}]^{+}\right)$. Since leoleorins A $(\mathbf{9})$ and B $(\mathbf{1 0})$ were reported (Cragg and Little, 1962; Kaplan and Rivett, 1968) before the advent of high resolution NMR instruments their ${ }^{1} \mathrm{H}$ and ${ }^{13} \mathrm{C}$ NMR assignments are presented here. The ${ }^{1} \mathrm{H}$ NMR spectrum of $\mathbf{9}$ (Table 1) exhibited the typical proton resonances of a $\beta$-substituted furan moiety at $\delta_{\mathrm{H}} 7.35,7.23$, and 6.28 , three methyl singlets at $\delta_{\mathrm{H}} 1.36,1.23$, and 1.18 , and one methyl doublet at $\delta_{\mathrm{H}} 1.28(J=6.8 \mathrm{~Hz})$, coupled with a vicinal proton $(2.78, \mathrm{q}, J=6.8$ $\mathrm{Hz})$. The signals of an $a, \beta$ - unsaturated carbonyl moiety were observed at $\delta_{\mathrm{H}} 6.12(\mathrm{~s}, \mathrm{H}-6)$, and $\delta_{\mathrm{C}} 175.3$ (C-5), 123.7 (C-6), 200.1 (C-7), which is in agreement with the UV absorption at $240 \mathrm{~nm}$. The structure and absolute configuration of 9 were unambiguously defined by single-crystal X-ray crystallography as $(8 S, 9 R, 10 S)$-15,16-epoxy-9a-

hydroxylabda-5,13(16),14-trien-7-one (Fig. 6)(Kaplan and Rivett, 1968). 
Leoleorin $\mathrm{C}(\mathbf{1 0})$ was isolated as a yellow oil, $[\alpha]_{\mathrm{D}}^{23}+23.9$. Comparison of the NMR spectroscopic data of $\mathbf{1 0}$ with those of $\mathbf{9}$ showed two additional sp ${ }^{2}$ carbon signals at $\delta_{\mathrm{C}}$ 130.8 and 163.1 , and replacement of the Me-17 doublet with singlet $\left(\delta_{\mathrm{H}} 1.95\right)$ in the spectrum of compound $\mathbf{1 0}$. These features suggested that $\mathbf{1 0}$ might derive from $\mathbf{9}$ via dehydration with formation of C-8 - C-9 double bond. Based on these data, compound $\mathbf{1 0}$ was identified as 15,16-epoxylabda-5,8,13(16),14-tetraen-7-one, which is identical with anhydro-Y obtained semi-synthetically from compound Y (Kaplan and Rivett, 1968).

\subsection{Binding affinities of isolated compounds to CNS receptors}

Compounds (1 - 11) were screened against a battery of 26 G-protein-coupled receptors including serotonin, adrenergic, dopamine, histamine, muscarinic acetylcholine, and opioid receptors. Additionally, the compounds were screened against biogenic amine transporters and the sigma1 and sigma2 receptors. The data (Table 3) demonstrate that some of the compounds displayed activity in several assays. Compounds 1, 6, 7, and 9 inhibited radioligand binding at the serotonin 5- $\mathrm{HT}_{1 \mathrm{~A}}$ receptor (inhibition: 62.3, 50.0, 61.9, and $60.4 \%$, respectively), while compound $\mathbf{8}$ showed $57.0 \%$ inhibition at the $5 \mathrm{HT}_{3}$ receptor. Compounds 1, 2, 5, and $\mathbf{6}$ showed activity at the D1-dopamine receptor (inhibition: 50.3, $57.4,62.3$, and $55.7 \%$, respectively). Compounds $2, \mathbf{3}, \mathbf{1 0}$, and $\mathbf{1 1}$ showed significant activity at the H1-histamine receptor (inhibition: 54.8, 56.3, 52.3, and 63.2\%, respectively). In addition, compounds $\mathbf{4}$ and $\mathbf{1 1}$ inhibited binding at the M3-acetylcholine, and sigma-1 receptors (inhibition: 55.1, and 59.1\%, respectively). In the secondary assay of competitive binding compound $\mathbf{1 1}$ showed moderate affinity $\left(K_{i}=2.9 \mu M\right.$ as compare to positive control, haloperidol $\mathrm{K}_{\mathrm{i}}=7 \mathrm{nM}$ ) for the Sigma 1 receptor. In all other assays, the compounds displayed $\mathrm{K}_{\mathrm{i}}$ values > 10,000 $\mathrm{nM}$ and were not pursued further.

\subsection{Concluding remarks}

Eight labdane diterpenoids (1-8) together with three known compounds (9-11), were isolated from leaves of $L$. leonurus. Their structures were established on the basis of spectroscopic methods as well as X-ray crystallographic analyses. In the radioligand binding assay, leoleorin C (11) showed moderate binding affinity $\left(K_{i}=2.9 \mu M\right)$ to the Sigma 1 receptor, which could be responsible for the psychoactive properties of this plant.

Many labdane diterpenoids were previously isolated from $L$. leonurus as well as other Leonotis species, and they may therefore serve as chemical markers for characterization of the Leonotis genus. In the current study, compounds 1-8 were obtained as new compounds in relatively high concentrations; their presence being overlooked in previous investigations is presumably attributable to variations of harvest time, geographical, climate, and environmental factors.

\section{Experimental}

\subsection{General Experimental Procedures}

Melting points were measured on OptiMelt MPA100 Automated Melting Point System and are uncorrected. Optical rotations were acquired with a Rudolph Research Analytical Autopol IV automatic polarimeter. IR spectra were recorded on a Bruker Tensor 27 spectrophotometer. NMR spectra were acquired on a Bruker DRX NMR spectrometer operating at $400 \mathrm{MHz}$ for ${ }^{1} \mathrm{H}$ and $100 \mathrm{MHz}$ for ${ }^{13} \mathrm{C}$ with a $3 \mathrm{~mm}$ direct carbon probe. The mass detector was time of flight (model G1969A) equipped with an electrospray ionization interface and was controlled by Aligent software (Aligent Mass Hunter Work Station, A. 02.01). 


\subsection{Plant Material}

Leafy freeze-dried material of L. leonurus was purchased from IAmShaman Shop (P.O. Box 12618 Chicago, IL 60612) in June 2010, and authenticated by one of the co-authors (Charles Burandt Jr.). A voucher specimen (Code: hkwu-LL-20101006) was deposited at the Department of Pharmacognosy, School of Pharmacy, University of Mississippi.

\subsection{Extraction and Isolation}

The dried and powdered leaves of $L$. leonurus $(411 \mathrm{~g})$ were extracted with acetone $(3 \times 2.0 \mathrm{~L}$; each $24 \mathrm{~h}$ ) by percolation at room temperature. The solvent was evaporated under reduced pressure at $40{ }^{\circ} \mathrm{C}$ to yield $42 \mathrm{~g}(10.2 \%)$ of a viscous syrup, which was dissolved in $\mathrm{CH}_{2} \mathrm{Cl}_{2}: \mathrm{MeOH}(60 \mathrm{~mL}, 1: 1$, v/v) and mixed with silica gel (85 g, 200-300 mesh), and dried at room temperature in a rotary evaporator under reduced pressure to give a fine powder. The latter was separated by silica gel column chromatography (CC) $(200 \mathrm{~g})$, eluted with hexanes-EtOAc (10:1, 4:1, 2:1, 1:1, 1:4, and 0:1, v/v) to give six sub-fractions A - F. Fr. A $(3.1 \mathrm{~g})$ containing fatty acids and pigments, was not studied further. Fr. B $(9.5 \mathrm{~g})$ was purified by Sephadex $\mathrm{LH}-20\left(\mathrm{CH}_{2} \mathrm{Cl}_{2}-\mathrm{MeOH} 1: 1\right)$, and then silica gel CC (100 g), eluted with hexanes-EtOAc (9:1, 7:1, 5:1, 3:1, v/v) to yield $\mathbf{9}(1 \mathrm{~g}), \mathbf{3}(1 \mathrm{~g}), \mathbf{1 1}(22 \mathrm{mg})$ and $\mathbf{1 0}(40$ $\mathrm{mg})$, respectively. Fr. C ( $2.8 \mathrm{~g})$ was purified by silica gel CC (100 g), eluted with hexanesEtOAc $(5: 1,4: 1,3: 1,2: 1, \mathrm{v} / \mathrm{v})$ to yield $4(630 \mathrm{mg})$ and $\mathbf{2}(100 \mathrm{mg})$. Fr. D $(5 \mathrm{~g})$ was purified by silica gel CC $(100 \mathrm{~g})$, eluted with hexanes-EtOAc $(3: 1,2: 1,1: 1, \mathrm{v} / \mathrm{v})$ to yield $5(500 \mathrm{mg})$ and $6(200 \mathrm{mg})$. Fr. E $(5.0 \mathrm{~g})$ was purified by silica gel CC (160 g), eluted with hexanesEtOAc (3:1, 2:1, 1:1, v/v) to yield 1 (300 mg). Fr. F (2 g) was purified by Sephadex LH-20 $\left(\mathrm{CH}_{2} \mathrm{Cl}_{2}-\mathrm{MeOH} 1: 1\right)$ and then silica gel CC $(160 \mathrm{~g})$, eluted with EtOAc to yield 7 (500 mg) and $\mathbf{8}(20 \mathrm{mg})$.

\subsection{Characterization of compounds}

\section{Leoleorin A [(8S,9R,10S)-15,16-epoxy-9a-hydroxylabda-5,13(16), 14-trien-7-}

one, 9]—white crystals (from EtOAc), mp 194-197 ${ }^{\circ} \mathrm{C} ;[\alpha]_{\mathrm{D}}^{23}-22.5$ (c 0.08, MeOH); UV $(\mathrm{MeOH}) \lambda_{\max }(\log \varepsilon) 240(4.17) \mathrm{nm}$; IR (KBr) $v_{\max } 3612,2943,1654,1519,1463 \mathrm{~cm}^{-1}$; for ${ }^{1} \mathrm{H}$ and ${ }^{13} \mathrm{C}$ NMR spectroscopic data, see Tables 1 and 2; ESIMS $\mathrm{m} / \mathrm{z} 317.2[\mathrm{M}+\mathrm{H}]^{+}$.

Leoleorin B (15,16-epoxylabda-5,8,13(16),14-tetraen-7-one, 10)-yellow oil; [ $\alpha]_{\mathrm{D}}^{23}$ +23.9 (c 0.1, MeOH); UV (MeOH) $\lambda_{\max }(\log \varepsilon) 245$ (3.98) nm; IR (KBr) $\nu_{\max } 2944,1651$, $1622,1465,1364 \mathrm{~cm}^{-1}$; for ${ }^{1} \mathrm{H}$ and ${ }^{13} \mathrm{C}$ NMR spectroscopic data, see Tables 1 and 2; ESIMS $m / z 299.2[\mathrm{M}+\mathrm{H}]^{+}$.

Leoleorin C (9,13-epoxy-6-hydroxylabdan-15,16-olide, 11)—white powder; $[\alpha]_{\mathrm{D}}^{23}$ $-2.1(c 0.8, \mathrm{MeOH})$; ESIMS $\mathrm{m} / \mathrm{z} 695.5[2 \mathrm{M}+\mathrm{Na}]{ }^{+} ;{ }^{1} \mathrm{H}$ and ${ }^{13} \mathrm{C}$ NMR spectroscopic data were identical with 9,13-epoxy-6-hydroxylabdan-16,15-olide (Naidoo et al., 2011).

Leoleorin $\mathrm{D}[(\mathbf{5 S}, 6 \mathrm{R}, \mathbf{8 R}, 9 \mathrm{R}, \mathbf{1 0 S}, \mathbf{1 3 S})-9,13-e p o x y l a b d a n e-6,15,16-t r i o l, 1]$-white crystals (from EtOAc), mp $116-117{ }^{\circ} \mathrm{C} ;[\alpha]_{\mathrm{D}}^{23}-7.5\left(c\right.$ 1.1, MeOH); for ${ }^{1} \mathrm{H}$ and ${ }^{13} \mathrm{C} \mathrm{NMR}$ spectroscopic data, see Tables 1 and 2; HR-ESIMS $\mathrm{m} / z 363.2499[\mathrm{M}+\mathrm{Na}]^{+}($calcd for $\mathrm{C}_{20} \mathrm{H}_{36} \mathrm{O}_{4} \mathrm{Na}, 363.2511$ ).

Leoleorin E (9,13:15,16-diepoxylabdane-6 $\beta, 15 \alpha$-diol, 2)—colorless oil; $[\alpha]_{\mathrm{D}}^{23}-3.3$ (c $0.06, \mathrm{MeOH}$ ); for ${ }^{1} \mathrm{H}$ and ${ }^{13} \mathrm{C}$ NMR spectroscopic data, see Tables 1 and 2; HR-ESIMS $\mathrm{m} / \mathrm{z}$ $361.2351[\mathrm{M}+\mathrm{Na}]^{+}$(calcd for $\mathrm{C}_{20} \mathrm{H}_{34} \mathrm{O}_{4} \mathrm{Na}, 361.2355$ ). 
Leoleorin $\mathbf{F}\left(\mathbf{9}, \mathbf{1 3}: \mathbf{1 5}, \mathbf{1 6}\right.$-diepoxylabdane-6 $\beta, \mathbf{1 6} \beta$-diol, 3)—colorless oil; $[\alpha]_{\mathrm{D}}^{23}-21.6$ (c $0.04, \mathrm{MeOH}$ ); for ${ }^{1} \mathrm{H}$ and ${ }^{13} \mathrm{C}$ NMR spectroscopic data, see Tables 1 and 2; HR-ESIMS $\mathrm{m} / \mathrm{z} 361.2357[\mathrm{M}+\mathrm{Na}]^{+}$(calcd for $\mathrm{C}_{20} \mathrm{H}_{34} \mathrm{O}_{4} \mathrm{Na}, 361.2355$ ).

16-epi-Leoleorin F (9,13:15,16-diepoxylabdane-6 $\beta, 16 \alpha$-diol, 4)—white powder; $[\alpha]_{\mathrm{D}}^{23}+30.0(c 0.2, \mathrm{MeOH})$; for ${ }^{1} \mathrm{H}$ and ${ }^{13} \mathrm{C}$ NMR spectroscopic data, see Tables 1 and 2; HR-ESIMS m/z $361.2359[\mathrm{M}+\mathrm{Na}]^{+}$(calcd for $\mathrm{C}_{20} \mathrm{H}_{34} \mathrm{O}_{4} \mathrm{Na}, 361.2355$ ).

Leoleorin G (9,13-epoxylabd-5-en-7-on-15,16-olide, 5)—colorless oil; [ $\alpha]_{\mathrm{D}}^{23}-20.5$ (c $0.4, \mathrm{MeOH}) ; \mathrm{UV}(\mathrm{MeOH}) \lambda_{\max }(\log \varepsilon) 233(4.06) \mathrm{nm}$; IR (KBr) $v_{\max } 2930,1783$, $1667,1167,1025 \mathrm{~cm}^{-1}$; for ${ }^{1} \mathrm{H}$ and ${ }^{13} \mathrm{C}$ NMR spectroscopic data, see Tables 1 and 2; HRESIMS $\mathrm{m} / \mathrm{z} 355.1889[\mathrm{M}+\mathrm{Na}]^{+}$(calcd for $\mathrm{C}_{20} \mathrm{H}_{28} \mathrm{O}_{4} \mathrm{Na}, 355.1885$ ).

Leoleorin $\mathbf{H}$ (15-acetoxy-9,13-epoxy-16-hydroxylabd-5-en-7-one, 6)—white powder; $[\alpha]_{\mathrm{D}}^{25}-29.5(c 0.4, \mathrm{MeOH})$; UV $(\mathrm{MeOH}) \lambda_{\max }(\log \varepsilon) 234(4.15) \mathrm{nm} ; \mathrm{IR}(\mathrm{KBr})$ $v_{\max } 3462,2930,1736,1665,1466,1367,1241 \mathrm{~cm}^{-1}$; for ${ }^{1} \mathrm{H}$ and ${ }^{13} \mathrm{C}$ NMR spectroscopic data, see Tables 1 and 2; HR-ESIMS $\mathrm{m} / \mathrm{z} 379.2468[\mathrm{M}+\mathrm{H}]^{+}\left(\right.$calcd for $\mathrm{C}_{22} \mathrm{H}_{35} \mathrm{O}_{5}$, 379.2484).

Leoleorin I (9,13-epoxy-15,16-dihydroxylabd-5-en-7-one, 7)—colorless oil; $[\alpha]_{\mathrm{D}}^{23}$ -36.5 (c 0.06, MeOH); UV (MeOH) $\lambda_{\max }(\log \varepsilon) 240$ (4.16) nm; IR (KBr) $\nu_{\max } 3368$, 2929, 1660, 1465, 1040, $985 \mathrm{~cm}^{-1}$; for ${ }^{1} \mathrm{H}$ and ${ }^{13} \mathrm{C}$ NMR spectroscopic data, see Tables 1 and 2; HR-ESIMS $\mathrm{m} / \mathrm{z} 359.2208[\mathrm{M}+\mathrm{Na}]^{+}$(calcd for $\mathrm{C}_{20} \mathrm{H}_{32} \mathrm{O}_{4} \mathrm{Na}, 359.2198$ ).

Leoleorin $\mathbf{J}\left(\mathbf{9}, \mathbf{1 3 - e p o x y l a b d - 5 - e n e - 7 \beta , 1 5 , 1 6 - t r i o l , ~ 8 ) - c o l o r l e s s ~ o i l ; ~}[\alpha]_{\mathrm{D}}^{23}-69.6(c\right.$ $0.02, \mathrm{MeOH}) ; \mathrm{IR}(\mathrm{KBr}) v_{\max } 3565,1650,1041,1024 \mathrm{~cm}^{-1}$; for ${ }^{1} \mathrm{H}$ and ${ }^{13} \mathrm{C} \mathrm{NMR}$ spectroscopic data, see Tables 1 and 2; HR-ESIMS $\mathrm{m} / \mathrm{z} 361.2359[\mathrm{M}+\mathrm{Na}]^{+}($calcd for $\left.\mathrm{C}_{20} \mathrm{H}_{34} \mathrm{O}_{4} \mathrm{Na}, 361.2355\right)$.

\subsection{X-ray Crystallography}

The crystal structures and absolute configuration of $\mathbf{1}$ and $\mathbf{9}$ were determined using data collected at $T=90 \mathrm{~K}$ with CuKa radiation ( $\lambda=1.54178 \AA$ ) on a Bruker APEX-II CCD diffractometer, equipped with an Oxford Cryostream cooler. Structures were solved using the program SHELXS-97 and refined anisotropically by full-matrix least squares on $F^{2}$ using SHELXL-97 (Sheldrick, 2008). OH hydrogen coordinates were refined; other H atoms were visible in difference maps, but were placed in idealized positions for the refinements. The absolute configurations were determined by refinement of the Flack (Flack, 1983) parameter based on resonant scattering of the light atoms and computation of the Hooft parameter (Hooft et al., 2008), in both cases yielding a probability of 1.000 that the reported configuration is correct. Crystal data: leoleorin D (1), $\mathrm{C}_{20} \mathrm{H}_{36} \mathrm{O}_{4}, M_{\mathrm{r}}=340.49$, orthorhombic space group $\mathrm{P} 2{ }_{1} 2_{1} 2_{1}, a=6.9830$ (3), $b=13.9703$ (6), $c=19.1528$ (8) $\AA, V=1868.44$ (14) $\AA^{3}, \mathrm{Z}=4, D_{X}=1.210 \mathrm{Mg} \mathrm{m}^{-3}, \theta_{\max }=69.4^{\circ}, R=0.027$ for 3472 data and 231 refined parameters. The Flack parameter is 0.08 (13) and the Hooft parameter is 0.04 (3) for 1452 Bijvoet pairs (98\% coverage); leoleorin A $(9), \mathrm{C}_{20} \mathrm{H}_{28} \mathrm{O}_{3}, M_{\mathrm{r}}=316.42$, orthorhombic space group P2 ${ }_{1} 2_{1} 2_{1}, a=6.5463$ (2), $b=11.4968$ (4), $c=22.8194$ (9) $\AA, V=1717.42$ (10) $\AA^{3}, \mathrm{Z}=$ $4, D_{\mathrm{x}}=1.224 \mathrm{Mg} \mathrm{m}^{-3}, \theta_{\max }=67.6^{\circ}, R=0.030$ for 3061 data and 216 refined parameters. The Flack parameter is 0.05 (18) and the Hooft parameter is 0.00 (9) for 1265 Bijvoet pairs ( $98 \%$ coverage). The crystal structures have been deposited with the Cambridge Crystallographic Data Centre, deposition numbers CCDC 86124 for leoleorin D (1) and CCDC 861242 for leoleorin A (9). 


\subsection{Radioligand Binding Assays}

Receptor binding profiles were generously provided by the National Institute of Mental Health's Psychoactive Drug Screening Program, Contract \# HHSN-271-2008-00025-C (NIMH PDSP). The NIMH PDSP is directed by Bryan L. Roth M.D., Ph.D. at the University of North Carolina at Chapel Hill and Project Officer Jamie Driscol at NIMH, Bethesda MD, USA. For initial screening, compounds were tested at concentrations of $10 \mu \mathrm{mol} / \mathrm{L}$. Detailed receptor-binding protocols are available at their web site (http:// pdsp.med.unc.edu).

\section{Highlights}

Eleven labdane diterpenoids were isolated from the leaves of Leonotis leonurus. Eight compounds were hitherto unknown. All compounds were evaluated for their binding affinities to various CNS receptors. Leoleorin C (11) showed weak binding affinity $\left(K_{i}=2.9 \mu M\right)$ to the Sigma 1 receptor.

\section{Supplementary Material}

Refer to Web version on PubMed Central for supplementary material.

\section{Acknowledgments}

The project was supported by a grant from National Institutes of Health (R03DA023491). We are grateful to Ms. Bin Wang at the Department of Pharmacognosy for assistance with the HRESIMS.

\section{References}

Agnihotri VK, ElSohly HN, Smillie TJ, Khan IA, Walker LA. Constituents of Leonotis leonurus flowering tops. Phytochem. Lett. 2009; 2:103-105.

Bienvenu E, Amabeoku GJ, Eagles PK, Scott G, Springfield EP. Anticonvulsant activity of aqueous extract of Leonotis leonurus. Phytomedicine. 2002; 9:217-223. [PubMed: 12046862]

Chizhov OS, Ryabokobylko YS, Kessenikh AV. NMR spectra of lagochilin. Russ. Chem. Bull. 1979; 28:1482-1484.

Cragg GML, Little GE. The extractives of Leonotis leonurus. J. S. Afr. Chem. Inst. 1962; 15:29-30.

El-Ansari MA, Aboutabl EA, Farrag ARH, Sharaf M, Hawas UW, Soliman GM, El-Seed GS. Phytochemical and pharmacological studies on Leonotis leonurus. Pharm. Biol. 2009; 47:894-902.

Flack HD. On enantiomorph-polarity estimation. Acta Cryst. 1983; A39:876-881.

Frum Y, Viljoen AM. In vitro 5-lipoxygenase and anti-oxidant activities of South African medicinal plants commonly used topically for skin diseases. Skin Pharmacol. Physiol. 2006; 19:329-335. [PubMed: 16931900]

Hooft RWW, Straver LH, Spek AL. Determination of absolute structure using Bayesian statistics on Bijvoet differences. J. Appl. Cryst. 2008; 41:96-103. [PubMed: 19461838]

Iwarsson, M. Flora of Southern Africa 28. Pretoria: Botanical Research Institute; 1985. p. 31-37.

Jimoh FO, Adedapo AA, Afolayan AJ. Comparison of the nutritional value and biological activities of the acetone, methanol and water extracts of the leaves of Solanum nigrum and Leonotis leonorus. Food Chem. Toxicol. 2010; 48:964-971. [PubMed: 20079394]

Kaplan ER, Rivett DEA. Structures of compounds X and Y, two labdane diterpenoids, from Leonotis leonurus. J. Chem. Soc. C. 1968:262-266.

Kruger GJ, Rivett DEA. Diterpenoids of Leonotis species. Part 7. The crystal and molecular structure of compound X, a labdane from L. leonurus. S. Afr. J. Chem. 1988; 41:124-125.

Laonigro G, Lanzetta R, Parrilli M, Adolfini M, Mangoni L. The configuration of the diterpene spiro ethers from Marrubium vulgare and from Leonotis leonurus. Gazz. Chim. Ital. 1979; 109:145-150. 
Maphosa V, Masika PJ, Bizimenyera ES, Eloff JN. In-vitro anthelminthic activity of crude aqueous extracts of Aloe ferox, Leonotis leonurus and Elephantorrhiza elephantina against Haemonchus contortus. Trop. Anim. Health Prod. 2010; 42:301-307. [PubMed: 19693685]

McKenzie JM, Green IR, Mugabo P. Leonurun, a novel labdane diterpenoid from Leonotis leonurus. S. Afr. J. Chem. 2006; 59:114-116.

Naidoo D, Maharaj V, Crouch NR, Ngwane A. New labdane-type diterpenoids from Leonotis leonurus support circumscription of Lamiaceae s.1. Biochem. Syst. Ecol. 2011; 39:216-219.

Obikeze KC, McKenzie JM, Green IR, Mugabo P. Characterization and cardiovascular effects of (13S)-9a,13a -epoxylabda-6 $\beta(19), 15(14)$ diol dilactone, a diterpenoid isolated from Leonotis leonurus. S. Afr. J. Chem. 2008; 61:119-122.

Ojewole JA. Antinociceptive, antiinflammatory and antidiabetic effects of Leonotis leonurus (L.) R. BR. [Lamiaceae] leaf aqueous extract in mice and rats. Methods Find. Exp. Clin. Pharmacol. 2005; 27:257-264. [PubMed: 16082426]

Oyedemi SO, Yakubu MT, Afolayan AJ. Antidiabetic activities of aqueous leaves extract of Leonotis leonurus in streptozotocin induced diabetic rats. J. Med. Plants Res. 2011; 5:119-125.

Rivett DEA. Isolation of marrubiin from Leonotis leonurus. J. Chem. Soc. 1964:1857-1858.

Scott G, Springfield EP, Coldrey N. A pharmacognostical study of 26 South African plant species used as traditional medicines. Pharm. Biol. 2004; 42:186-213.

Sheldrick GM. A short history of SHELX. Acta Cryst. 2008; A64:112-122.

Stafford GI, Jäger AK, Van Staden J. Effect of storage on the chemical composition and biological activity of several popular South African medicinal plants. J. Ethnopharmacol. 2005; 97:107-115. [PubMed: 15652284]

Stafford GI, Pedersen ME, Van Staden J, Jäger AK. Review on plants with CNS effects used in traditional South African medicine against mental diseases. J. Ethnopharmacol. 2008; 119:513537. [PubMed: 18775771]

Wu H, Fronczek FR, Ferreira D, Burandt CR Jr, Zjawiony JK. Labdane diterpenoids from Leonurus sibiricus. J. Nat. Prod. 2011; 74:831-836. [PubMed: 21375312] 

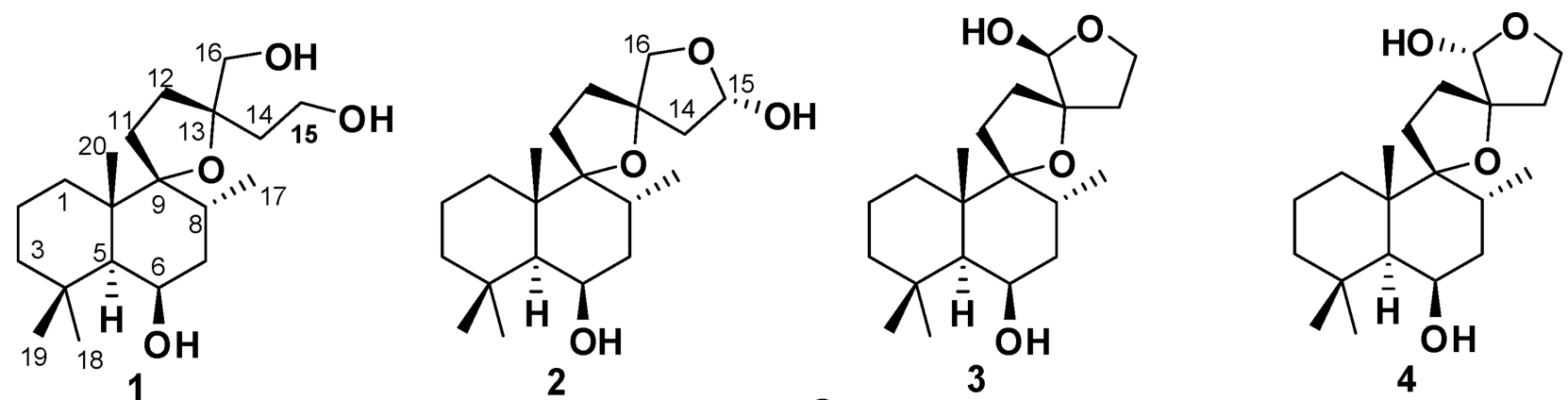

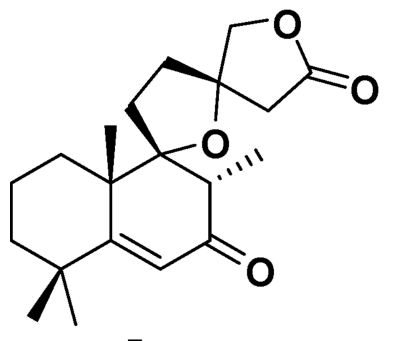

5<smiles>C[C@H]1C(=O)C=C2C(C)(C)CCC[C@]2(C)[C@]1(C)Cc1ccoc1</smiles>

9<smiles></smiles>

6<smiles>CC1=C(CCc2ccoc2)[C@]2(C)CCCC(C)(C)C2=CC1=O</smiles>

10

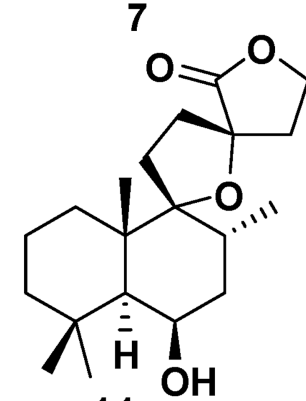

11

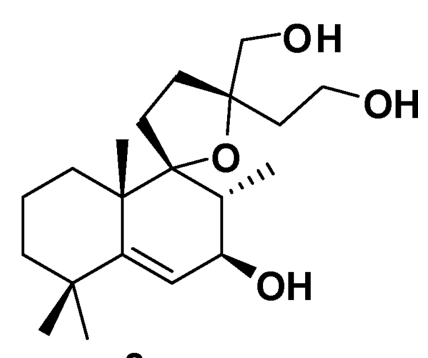

8

Figure 1.

Structures of compounds 1-11. 


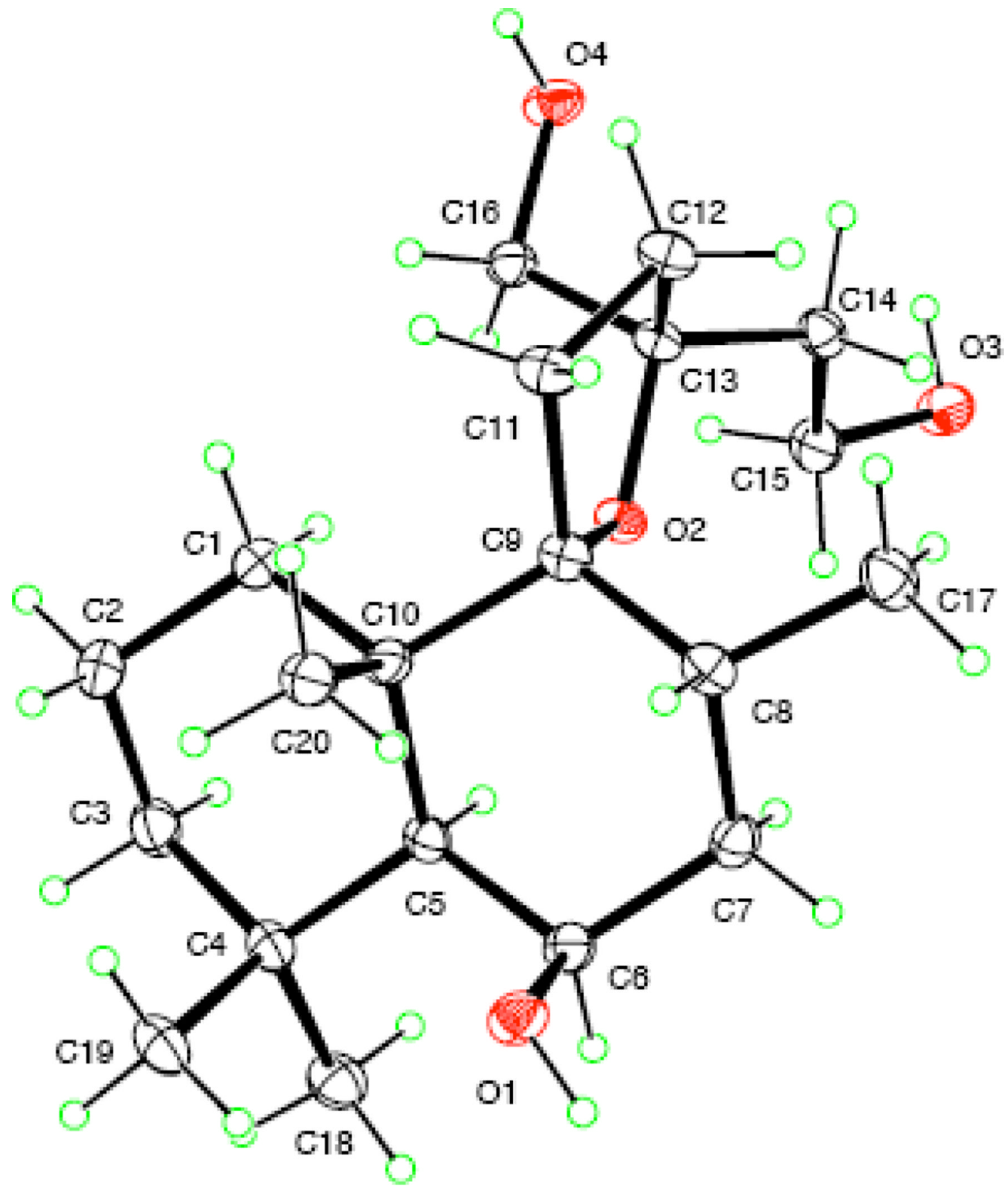

Figure 2.

ORTEP drawing of $\mathbf{1}$. 


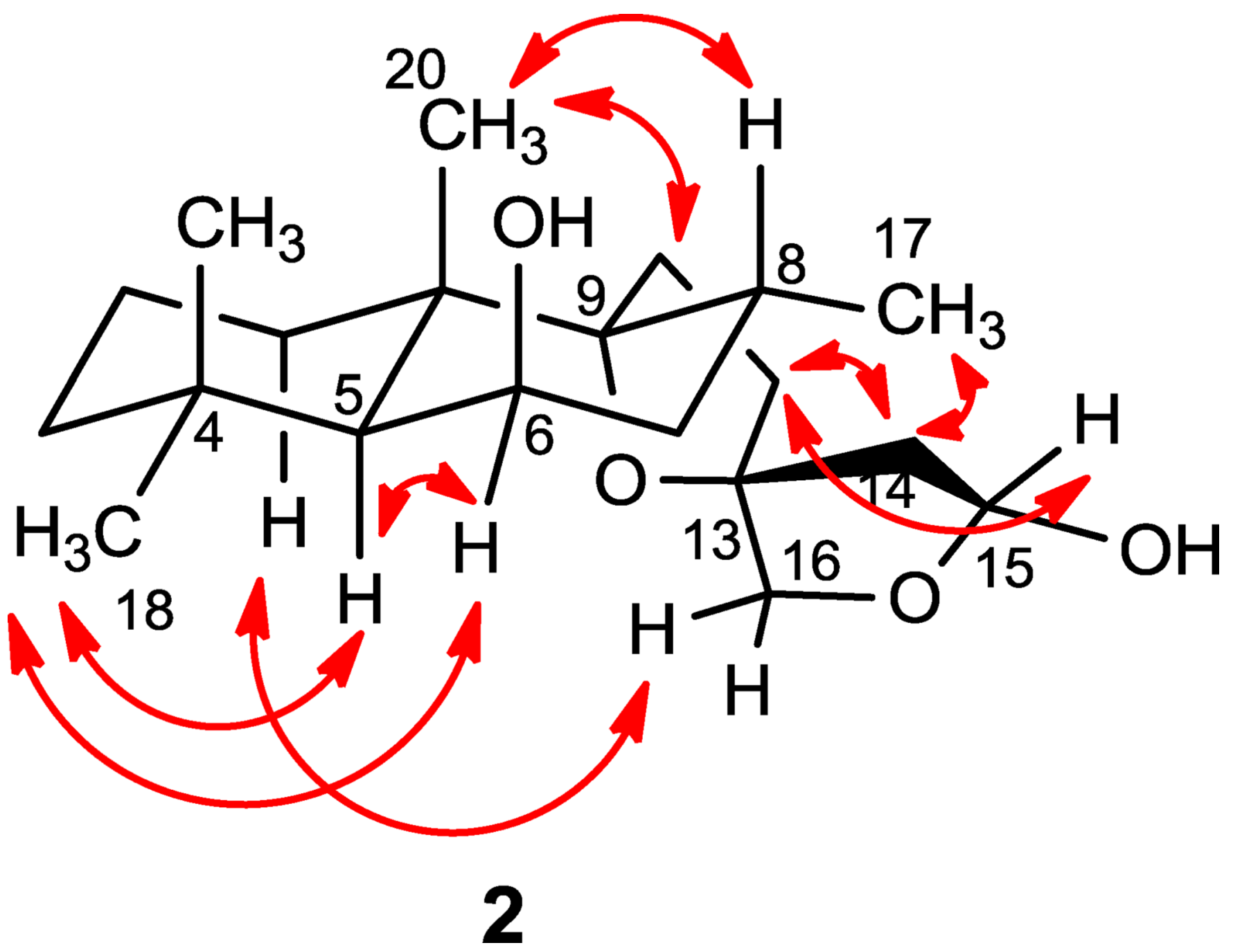

Figure 3.

Key NOESY correlations of 2. 


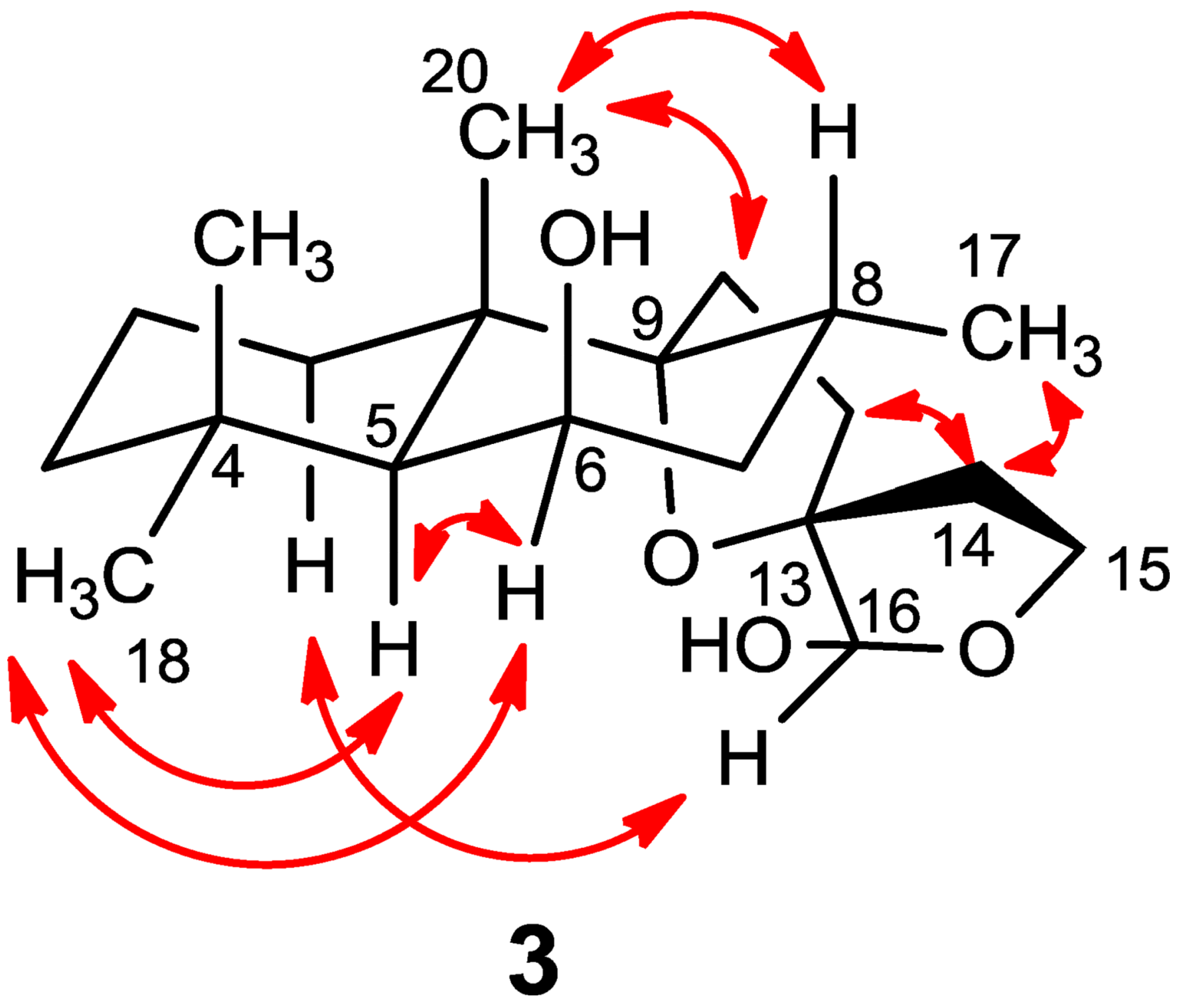

Figure 4.

Key NOESY correlations of $\mathbf{3}$. 


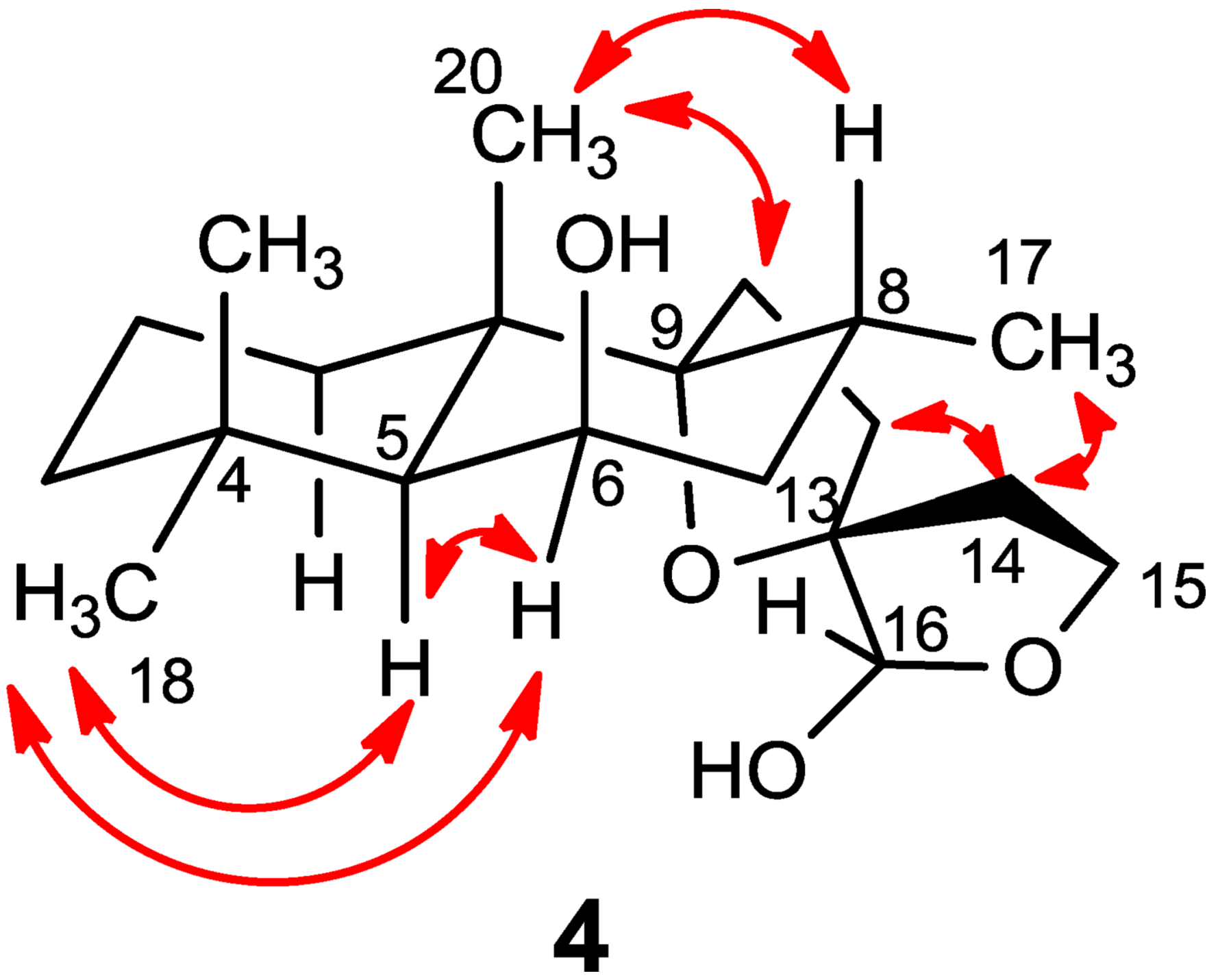

Figure 5.

Key NOESY correlations of 4. 


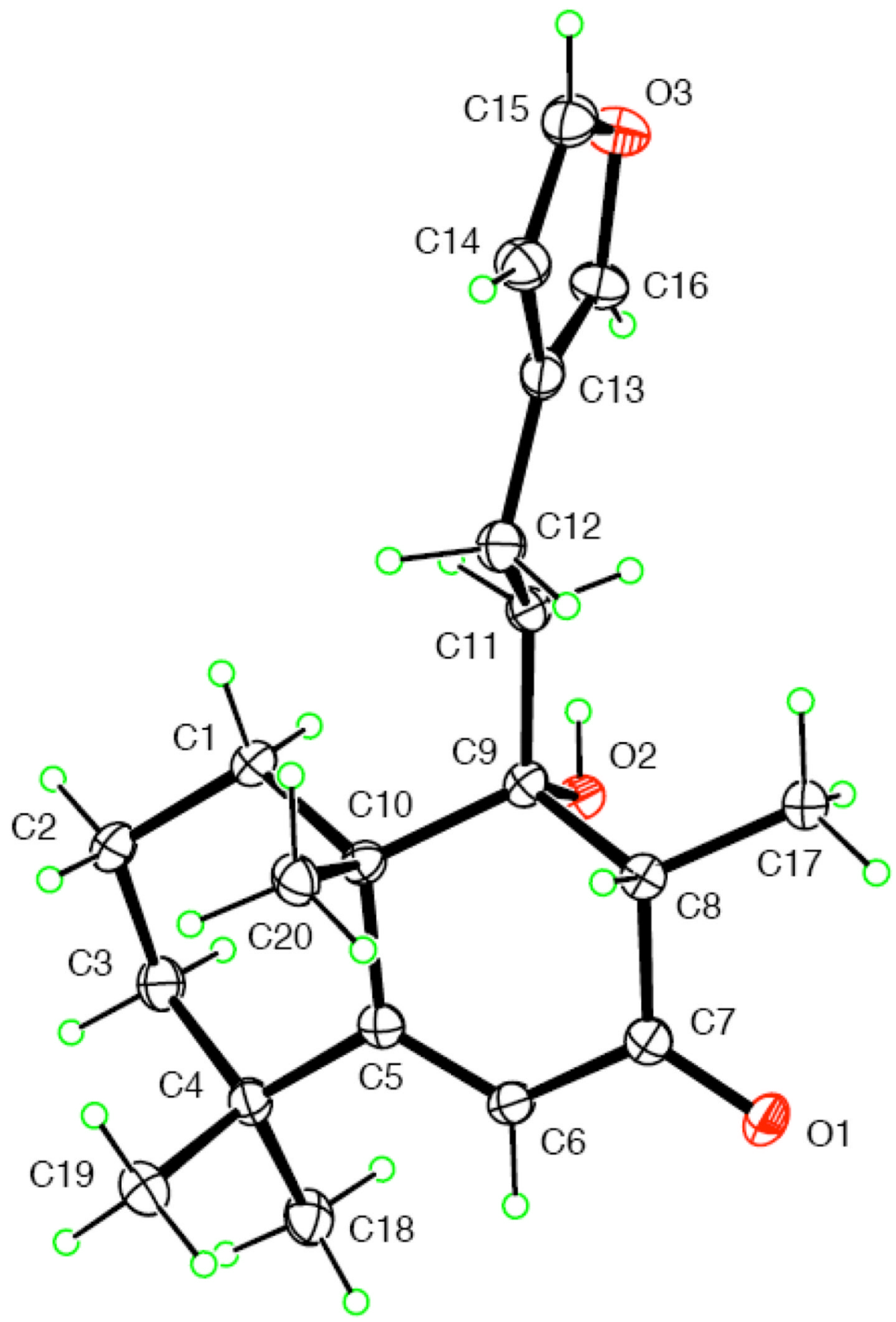

Figure 6.

ORTEP drawing of 9. 


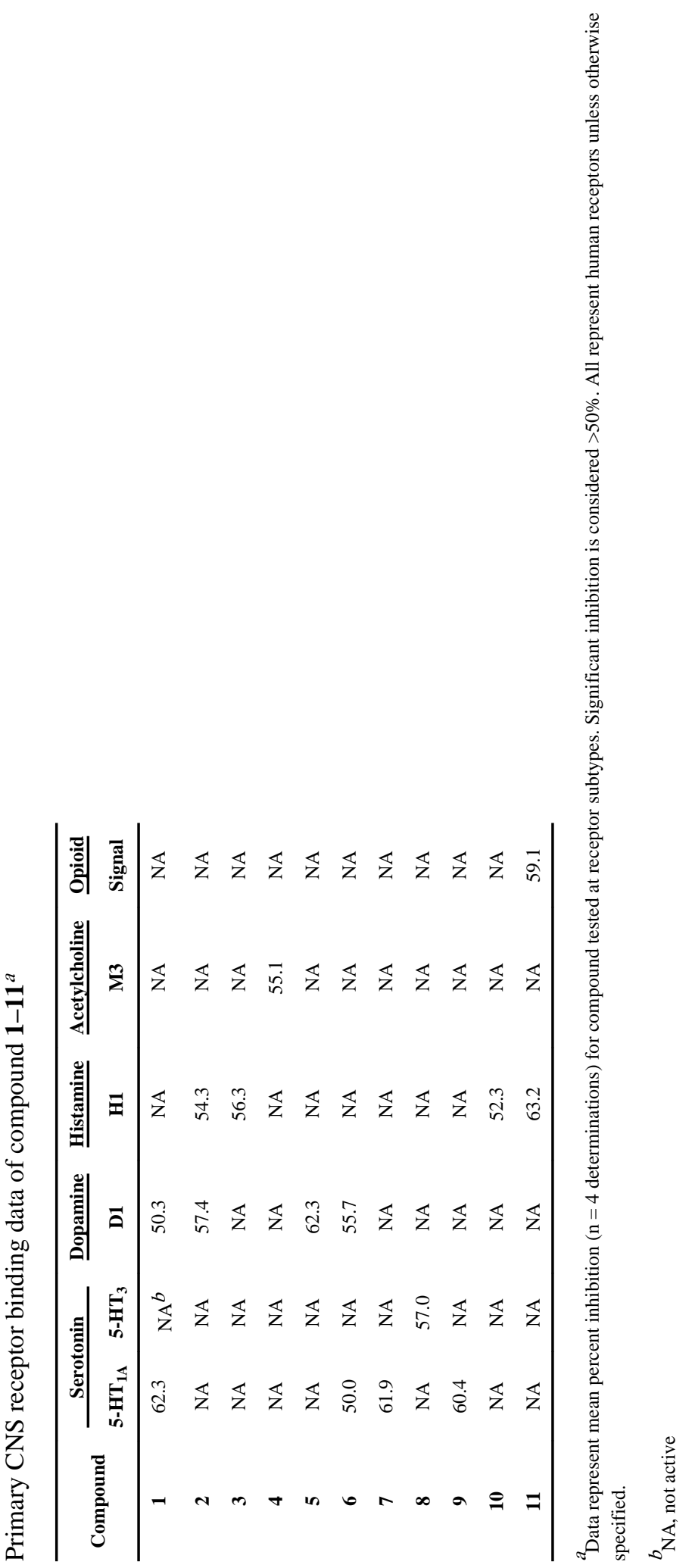

Phytochemistry. Author manuscript; available in PMC 2014 July 01. 